\title{
Emerging role of cancer stem cells in the biology and treatment of ovarian cancer: basic knowledge and therapeutic possibilities for an innovative approach
}

\author{
Federica Tomao ${ }^{1}$, Anselmo Papa ${ }^{2 *}$, Luigi Rossi ${ }^{2}$, Martina Strudel ${ }^{2}$, Patrizia Vici ${ }^{3}$, Giuseppe Lo Russo²
} and Silverio Tomao ${ }^{2}$

\begin{abstract}
In 2013 there will be an estimated 22,240 new diagnoses and 14,030 deaths from ovarian cancer in the United States. Despite the improved surgical approach and the novel active drugs that are available today in clinical practice, about $80 \%$ of women presenting with late-stage disease have a 5 -year survival rate of only $30 \%$. In the last years a growing scientific knowledge about the molecular pathways involved in ovarian carcinogenesis has led to the discovery and evaluation of several novel molecular targeted agents, with the aim to test alternative models of treatment in order to overcome the clinical problem of resistance. Cancer stem cells tend to be more resistant to chemotherapeutic agents and radiation than more differentiated cellular subtypes from the same tissue. In this context the study of ovarian cancer stem cells is taking on an increasingly important strategic role, mostly for the potential therapeutic application in the next future. In our review, we focused our attention on the molecular characteristics of epithelial ovarian cancer stem cells, in particular on possible targets to hit with targeted therapies.
\end{abstract}

Keywords: Epithelial ovarian cancer, Ovarian cancer stem cells, Chemoresistance, Target therapy

\section{Introduction}

Epithelial ovarian cancer (EOC), a tumor originating from ovarian epithelial surface, includes different histological subtypes [1-3]. In 2013, there will be an estimated 22,240 new diagnoses and 14,030 deaths from this neoplaia in the United States $[4,5]$.

It is the fifth most frequent cause of death from cancer in females and the most lethal cancer among gynecological tumors, with severe impact on public health and social costs [6-9]. Unfortunately, unlike other gynecologic cancers, etiology of EOC is still unkown [10]; and for biological and clinical reasons EOC is still diagnosed and treated at a very advanced stage; still now an early diagnosis is very difficult and infrequent and a validated program of screening for this tumor is still lacking [11-13].

\footnotetext{
* Correspondence: anselmo.papa@libero.it

${ }^{2}$ Department of Medico-Surgical Sciences and Biotechnologies, University of Rome "Sapienza", Latina, Italy

Full list of author information is available at the end of the article
}

Furthermore, despite the improved surgical approach and the novel active drugs that are available today in clinical practice, at the time of diagnosis about $80 \%$ of women have an advanced disease, with a 5-year survival rate of only $30 \%$ [12]; probably, one of the possible reasons could be the ovarian cancer cells ability to develop resistance mechanisms to the drugs through congenital and acquired genetic characteristics [14].

However, the response rate to chemotherapy is high, sometimes impressive and about the $75 \%$ of patients initially respond to conventional chemotherapy; moreover clinical and pathological complete remission is possible, sometimes frequent, but unfortunately $>80 \%$ of these women experience relapse and die for the progression and diffusion of chemotherapy resistant disease. In fact, patients with recurrent EOC usually receive multiple lines of chemotherapy, with disappointing and unsatisfactory results, due to the occurrence of drug-resistant clones $[15,16]$. The pharmacological activity of drugs used in EOC could be reduced by a biological phenomenon that is 
able to induce the transformation of epithelial to mesenchymal cells (EMT) and the progression, invasion and diffusion of the tumor [17]. In the last years a growing scientific knowledge about the molecular pathways involved in ovarian carcinogenesis has led to the discovery and evaluation of several novel molecular targeted agents, with the aim to test alternative models of treatment in order to overcome the clinical problem of resistance. In this context the study of ovarian cancer stem cells (CSCs) is taking on an increasingly important strategic role, mostly for the potential therapeutic application in next future [18]. Now we know that selfrenewing ovarian CSCs or ovarian cancer-initiating cells, and mesenchymal stem cells (SCs) too, are probably implicated in the etiopathogenesis of EOC, in its intra- and extra-peritoneal diffusion and in the occurrence of chemoresistance [19]. EOC can be classified into multiple types (serous, endometrioid, clear cell, and mucinous), with different clinical- pathologic properties, prognostic characteristics and therapeutic outcomes [20-22].

Moreover, several works support the fact that all histological cell types of EOC have different cellular origin with specific biologic and genetic profiles [23-27].

Consequently, the CSC population for each type may also be variable. It is therefore not surprising that SC properties have been reported in EOC cells isolated using different cell surface markers, including CD44, CD133 or CD24. Each of these EOC cells may represent either a hierarchy of CSC or an entirely different population of CSC for that particular ovarian histology [28-33]. CSCs support the succession of clonal tumor cell proliferation and repopulation in the tumor microenvironment. In fact they are predominantly quiescent, have up-regulated DNA repair capacity, are noncommittal to apoptosis and overexpress ATP-binding cassette $(\mathrm{ABC})$ drug efflux transporters and a profusion of cancer gene signatures [34,35].

The optimal management modality for EOC includes histopathological diagnosis and staging, surgical debulking of tumor, and the use of several cycles of chemotherapy with carboplatin and paclitaxel at maximum tolerated doses, eventually associated with bevacizumab, followed by maintenance or salvage treatments, in cases of disease recurrence [36]. Moreover, the majority of standard or experimental regimens have not yet improved efficacy or significantly reduced adverse effects over the combination of carboplatin, paclitaxel and bevacizumab, suggesting that other therapeutic experimental strategies are necessary in order to prolong progression free survival (PFS) and overall survival (OS) rates in ovarian cancer patients [37-43]. There is a critical need to develop broad-spectrum as well as individualized molecular-targeted therapies for EOC, and so current research interest is to identify signal transduction pathways and target key molecular role players that direct ovarian tumor sensitivity and resistance to therapy $[44,45]$. The aim of this review is to outline recent developments in our understanding of the interrelationships among selected ovarian CSC biomarkers, heterogeneous expression signatures and related molecular signal transduction pathways, and their translation into futuristic as well as more efficacious targeted treatment strategies.

\section{Cancer stem cell}

A recent American Association for Cancer Research (AACR) workshop defined CSC as a malignant cancer cell with a stem cell phenotype [35]. Whilst the CSC hypothesis does not specifically address the mechanisms of malignant transformation, it has been suggested that CSCs are the malignant counterparts of normal adult tissue SCs which, due to dysregulated signaling pathways, are unable to maintain stem cell homeostasis. As well as the normal Scs, also CSCs are thought to reside at the top of the lineage hierarchy and give rise to differentiated cells, which themselves have no potential for self-renewal, and therefore do not contribute significantly to tumor growth. Due to their long life, SCs remain in a tissue for longer periods compared to their differentiated progeny, thereby making them more likely to acquire transforming mutations. Additionally, it is generally accepted that SCs are more resistant to apoptosis and DNA damage and they are therefore more likely to survive to any insults $[46,47]$. Whilst being quiescent in normal tissue, SCs are able to maintain their pool by undergoing asymmetric cell division during biological processes such as the occurrence of tissue damage. During this process, a SC divides asymmetrically to generate an identical daughter cell that is committed to differentiation. It has been suggested that in this way CSCs generate the different cell types within a tumor, leading to tumor self-renew as well.

Specific signaling pathways are involved in embryogenesis processes, leading to the development of various organs. We are talking about several key pathways, such as sonic Hedgehog, Notch, PTEN, BMI-1, WNT, and p53. During the development of cancer an alteration of these pathways occurs and this event could lead to dysregulation of SC self-renewal and contribute to tumor proliferation $[19,48]$. The SC pool is also tightly regulated by signaling pathways from the microenvironment of the SC niche, and several of these pathways, including Hedgehog and Wnt, have been implicated in carcinogenesis $[49,50]$. This may have very important implications in therapeutic interventions, including explanation for the development of chemoresistance. A role for CSCs in propagating and maintaining metastases has been proposed [51-54]. The different hypothesis that the dedifferentiation of mature cells to a more pluripotent state could be a potential mechanism for the development of SC-like features by cancer cells, cannot be 
dismissed. In 1997 Bonnet and Dick first isolated the CSCs in leukemic cells expressing SC marker CD34 and afterwards, also, in other solid tumors [55-64]. Classically, SCs are defined by their two main characteristics: self-renewal and pluripotency [63]. Experiments performed on human acute myeloid leukemia and solid tumors show that CSC have three functional characteristics:

- transplantability, tumorigenic potential to form tumors when injected into nude mice;

- distinct surface markers;

- ability to recreate the full phenotypic heterogeneity of the parent tumor [64-66].

In characterizing normal and CSC $\mathrm{s}$ the problem is that these cellular populations are rare and the absence of specific cell surface markers represents a challenge to isolate and identify pure SC populations [67-72].

\section{Cancer stem cell markers}

The limitation of using cell surface marker expression to characterize CSCs is that this approach requires prior knowledge of cell surface markers that are expressed by the putative CSCs in the tissue of interest, and often the choice of markers is inferred from known expression of markers in normal adult SCs. Several studies have prospectively isolated CSCs by looking for the presence of extracellular markers that are thought to be SC specific. The markers most commonly used are CD133 and CD44. [73]. These markers have been used successfully to isolate SCs in normal and tumor tissue $[74,75]$. Whilst CD133 and CD44 are thought to be indicative of a CSC phenotype, it is not clear if they are universal markers for characterizing CSCs derived from all types of tumors. Furthermore, expression of CD133 and CD44 may not be restricted to the CSC population and may be present in early progenitor cells.

The pentaspan transmembrane glycoprotein CD133, also known as Prominin-1, was originally described as a hematopoietic stem cell marker [73] and was subsequently shown to be expressed by a number of progenitor cells including those of the epithelium, where it is expressed on the apical surface [76]. Regarding EOC, Ferrandina G et al. demonstrated that $\mathrm{CD} 133(+)$ cells gave rise to a larger number of colonies than those documented in a CD133(-) population. Moreover, CD133(+) cells showed an enhanced proliferative potential compared to CD133(-) cells. The percentages of CD133-1 and CD133-2 epitopes expressing cells were significantly lower in normal ovaries/benign tumors with respect to those in ovarian carcinoma. Both the percentages of CD133-1- and CD133-2-expressing cells were significantly lower in metastases than in primary ovarian cancer. They didn't detect any difference in the distribution of the percentage of CD133-1- and CD133-2-expressing cells according to clinicopathologic parameters and response to primary chemotherapy. Using flow cytometry, Ferrandina et al. reported that CD133-1 and CD133-2 were both expressed in human ovarian tumors at higher frequency than in normal ovaries and metastatic omental lesions. CD133-1 and CD133-2 may be useful, therefore, to select and enrich population of CD133(+) ovarian tumor cells that are characterized by a higher clonogenic efficiency and proliferative potential [77].

Moreover, in 2009 Baba et al. found that CD133 expression is repressed concomitant with the acquisition of DNA methylation in CD133- progeny of CD133+ cells supports a role for CD133 in the CD133+ cells, which is not required in the CD133- cells after asymmetric division [78].

According to these discoveries, Curley et al. found that tumor-derived CD133-1 cells have an increased tumorigenic capacity and are capable of recapitulating the original heterogeneous tumor [79].

Aldehyde dehydrogenase (ALDH), a reported CSC marker in several solid tumors, has been studied in association to CD133 in order to identify a set of markers to identify ovarian CSCs. Siva et al. discovered that the presence of $\mathrm{ALDH}(+) \mathrm{CD} 133(+)$ cells in debulked primary tumor specimens correlated with reduced disease-free and overall survival in ovarian cancer patients [31].

CD44 is a surface molecule which mediates cell adhesion and migration by binding extracellular matrix components such as hyaluronic acid, osteopontin, or activating receptor tyrosine kinases, which are related with tumor progression and metastasis $[55,80]$. Bapat et al. found that the growth factor receptors c-met and epidermal growth factor receptor were up-regulated in ovarian CSCs as well as CD44. They also expressed E-cadherin. Correspondingly, Snail, a known mediator of EMT through transcriptional repression of E-cadherin, was expressed in some CSC clones and to a lesser extent in others [22]. It has been demonstrated that CD44+CD117+ cells are often present in EOC. CD117, beyond his role in cancer initiating cells from primary human tumors, has been used as stem cell marker for identification and characterization of hematopoietic stem and progenitor cells, of cardiac CD117-positive stem cells in adult human heart and other mesenchymal stem cells. Chen et al. demonstrated in vitro that human epithelial ovarian cancer CD44 + CD117+ cells possessed the properties of let the tumor be chemoresistant to conventional therapies, such as $5 \mathrm{FU}$, docetaxel, cisplatin, and carboplatin [81].

CD44 has also been demonstrated to be associated with other CSC markers. In fact,Wei at al., investigating about Müllerian Inhibiting Substance with the aim of inhibit stem/progenitors in EOC, identified eight marker panel on three human ovarian cancer cell lines and found that the combination of Epcam ${ }^{+}, \mathrm{CD} 24^{+}$, and $\mathrm{CD} 44^{+}$formed 
more colonies than other marker combinations. It was necessary to use this $3+$ panel in combination, as each marker alone was not sufficiently selective [82].

Goodell et al. first reported a small population of cells showing distinct fluorescent-activated cell sorting profile off to the side of the main population due to a more efficient Hoechst dye efflux and lower fluorescent intensity signal. This subset of cells is referred to as the side population (SP) and is enriched for HSCs from murine bone marrow [83]. Many studies of SP have been performed in a number of cancers such as leukemias, brain, prostate, gastrointestinal tract, melanoma, retinoblastoma, and many cancer cell lines, leading to the hypothesis that the SP is enriched with CSC [84-90].

Szotek and colleagues investigated on several markers of SP and non-SP cells, such as c-kit/CD117, CD44, CD24, CD34, CD105, CD133, Sca-1, CD24, Ep-CAM. Taken together, all CSC surface markers investigated here are indicators, but definitely not a reliable marker for defining a population of CSCs in solid tumors since they do not characterize tumorinitiating cells exclusively. To increase the sensitivities and specificities for the detection of CSCs, further investigations are needed [91,92].

CD24 is a glycosylphosphatidylinositol-linked cell surface protein expressed in various solid tumors [93].

Gao et al. have successfully isolated CD24+ CSCs from ovarian tumor specimens and identified CD24 as a putative CSC marker in EOC [94]. The depletion and overexpression of $\mathrm{CD} 24$ could regulate the phosphorylation of STAT3 and FAK by affecting Src (non-receptor tyrosine kinases) activity. CD117, known as c-kit, is a type III receptor tyrosine kinase involved in cell signal transduction. It is involved in various cellular processes, including apoptosis, cell differentiation, proliferation, and cell adhesion [95]. High expression level of CD117 was observed in ovarian cancers [22].

Luo and his colleagues further demonstrated that CD117+ ovarian cancer cells had the ability to selfrenew, differentiate, and regenerate tumor compared to CD117- in xenograft model [96]. It has been also suggested that CD117 in ovarian carcinoma was associated with poor response to chemotherapy [97].

The activation of Wnt/ $\beta$-catenin-ATP-binding cassette G2 pathway was required for cisplatin/paclitaxel-based chemoresistance caused by CD117 in ovarian CSCs [98].

The epithelial cell adhesion molecule EpCAM is a glycosylated membrane protein. It is highly expressed in different tumor types, including colon, lung, pancreas, breast, head and neck and ovary [99]. EpCAM was found to be hyperglycosylated and frequently associated with cytoplasmic staining in carcinoma tissues [100]. EpCAM is comprised of an extracellular domain (EpEX), a single transmembrane domain and a short 26-amino acid intracellular domain (EpICD). Among them, EpEX is required for cell-cell adhesion [101]. Down-regulation of EpCAM could cause loss of cell-cell adhesion and promote EMT $[102,103]$.

A valid marker among several malignant and non malignant tissues is aldehyde dehydrogenase-1A1 (ALDH1A1). ALDH1A1 is an intracellular enzyme that oxidizes aldehydes; it has a detoxifying role, and allows the conversion of retinol to retinoic acid, making a management of the differentiation pathways. It holds the attractive distinction of not only being a potential marker of "stemness," but potentially playing a role in the biology of tumor initiating cells as well [104-110]. ALDH1A1 was identified as a putative CSC marker, and it was associated with chemoresistance in the ovarian CSC [111].

In one case, clones have been identified from tumor ascites; they were able to form anchorage-independent spheroids and have shown to express the SC markers Oct $3 / 4$, Nanog and the progenitor marker Nestin [112].

Szotek et al. used flow cytometry to isolate a SP of cells from genetically engineered mouse ovarian cancer cell lines that expressed the multidrug transporter protein BCRP1 and were resistent to doxorubicin, suggesting a possible link between CSCs and chemoresistance. They also isolated a similar smaller SP of cells from the human ovarian cancer cell lines IGROV-1, OVCAR3, and SKOV3, but these SP cells were not further characterized [91]. Two other studies have independently defined ovarian cancer SC by evaluating CD44+ CD117+ and CD133+ phenotypes. The latter suggests an epigenetic regulation of the CD133 promoter [22,29]. Additionally, using CD44, stem-like cells were enriched from patients' samples and were characterized by Myd 88 expression and chemokine and cytokine production [20]. Despite the different profiles described for CSCs by these studies, both studies reported that the CSC phenotype was more resistant to platinum based therapy, which again supports the theory that CSCs may be responsible for chemoresistance. Generally, these studies highlight the lack of consensus about the molecular characteristics of ovarian CSCs. It is likely that the expression of markers overlaps and both CD133 and CD44 characterize the ovarian CSC. Alternatively, there may be more than one population of cells with SC properties in ovarian cancers. The study by Bapat et al. postulated that SCs are the target of transformation in ovarian cancer because few clones isolated from ovarian cancer ascites spontaneously immortalized in culture, suggesting a model for disease development. In their study, about mutant mitochondrial genome, Wani et al. highlighted the importance of tumor status suppressor gene - cAMP responsive element binding protein (CREBBP); in fact the mutation of this gene could be used by a normal SC to overcome the DNA repair in the its evolution towards tumorigenesis [113]. 
Other mechanisms leading to SC enrichment under conditions of stress include heightened DNA damage response and repair, both contributing significantly to tumor survival $[114,115]$.

\section{Resistance to conventional therapies}

Although the standard combination of surgery and chemotherapy can effectively reduce tumor mass, most patients, eventually with residual ovarian CSCs, acquire chemoresistance [116-121]. The CSC theory supports that even if a small number of CSCs remains in situ after therapy, disease recurrence can occur [19]. Several pathways could be involved in these mechanisms including activation of anti-apoptotic factors, inactivation of pro-apoptotic effectors, and/or reinforcement of survival signals [122]. Based on an understanding of their characteristics, the refractory response of CSCs to drugs and radiation treatments may be attributed to:

- drug effluxion

- glutathione (GSH) system

- apoptosis;

- enrichment of CSCs during disease progression

- tumor dormancy and CSC quiescence

\section{Drug effluxion}

It can be caused by an altered uptake or efflux of drug in the target cell. Platinum compounds enter the cell, primarily by passive diffusion, however several different ways have been described such as copper transporter proteins (CTR), organic cation transporters (OCTs) from de SLC22 family, ATP-binding cassette $(\mathrm{ABC})$ multidrug transporters, copper-transporting ATPases, and multidrug and toxin extrusion from the SLC47 subfamily members that might facilitate the active efflux of anticancer platinum agents. Some of most frequently studied drug transporters associated with acquisition of resistance in normal SCs as well as in CSCs are multifunctional efflux transporters from the $\mathrm{ABC}$ gene family [123]. These contribute to tumor resistance by actively transporting drugs across cell membranes through ATP hydrolysis [83,124-127]. Efflux transporters in the $A B C$ family such as ABCG2 are cell surface drug-resistance markers involved in the transport of substances and cellular products [128-133]. The resistance gene BCRP/MXR/ $\mathrm{ABCP}$ has been studied for its involvement in development of chemoresistance. ABCG2/BCRP plays a key role in cellular homeostasis and tissue integrity. It has been observed that ovarian CSCs exposed to chemotherapy overexpress this $\mathrm{ABC}$ family of transporters. Consequently, ABCG2/BCRP acts as a xenobiotic drug transported by promoting expulsion through an ejection system.

\section{Glutathione (GSH) system}

Also inflammatory processes can contribute to multiple CSC capabilities by supplying bioactive molecules to the tumor microenvironment and, additionally, inflammatory cells can release reactive oxygen species that are actively mutagenic for nearby cancer cells and accelerate their genetic evolution toward states of heightened malignancy [134].

GSH system protects cells against the effect of external cytotoxic agents, including platinum $[135,136]$. The GSH system can suppress oxidative stress and maintain cellular redox homeostasis [137]. The contribution of GSH and GSH-related enzymes to chemoresistance has been demonstrated in different types of tumor, including ovarian cancer and brain tumor [138]. GSH is also involved in the detoxification of various xenobiotics [139]. Upon metabolism of chemotherapeutic agents, the enzymes of glutathione-S-transferase (GST) family could prompt the formation of GSH-drug conjugates. Many chemotherapeutic agents have been shown to conjugate with GSH, including chloroethylnitrosoureas, platinum compounds, and other alkylating agents. The resulting GSH drug conjugates are more water soluble and less active than the compounds themselves. They are thus exported from the cell via the transporter-mediated system [140].

Basing on these data we can affirm that GST can lead to a loss of response to chemotherapeutic agents, including those that are usually employed in the treatment of ovarian cancer. Some authors let us think that this is particularly significant in cancer cells with stem-cell like properties. In a recent study, it has been shown that platinum-resistant human cancer cells with stem-cell like EMT properties, had high cellular GSH and accumulated significantly less cellular platinum compared to their parental cells, and failed to undergo apoptosis when exposed to platinum at the drug concentrations toxic to the parental cells [140].

\section{Apoptosis}

Apoptosis can condition response to antitumor drugs and it's regulated by several molecular phenomena, such as the expression of Bm-1 and the loss of $\mathrm{p} 53$.

Bmi-1, a member of the polycomb group (PcG) family, participates in the self-renewal and maintenance of CSCs [141]. As an oncogene, Bmi-1 could enable cancer cells to escape apoptosis by modulating multiple growth signaling pathways [142]. Thus, its overexpression in cancer cells could be used as a survival marker. The role of Bmi-1 in chemoresistance has been addressed recently $[143,144]$. For ovarian cancer cells, silencing of Bmi- 1 gene could promote sensitivity to cisplatin and induction of apoptosis [145].

The tumor suppressor gene p53 plays a critical role in cell proliferation and apoptosis by controlling several 
signaling pathways. In addition, the control of intracellular localization of p53 is also associated with the regulation of apoptosis and chemosensitivity in human ovarian cancer cells [146-148]. Loss of p53 function correlates with multidrug resistance in several tumor types, including EOC [149].

\section{Enrichment of CSCs during disease progression}

Enrichment of CSCs in tumor tissues is reported in patients with response to therapy through mechanisms such as enhanced DNA damage repair and changes in the cellular phenotype between epithelial and mesenchymal states of cell [150]. EMT is a physiological transcriptional reprogramming event and is characterized by the combined loss of epithelial cell junctions and cell polarity and the gain of a mesenchymal phenotype. EMT and mesenchymal to epithelial transition (MET) processes are now recognized in cancer progression [151]. A link between CSC and EMT has been suggested, whereby transformed human mammary epithelial cells, that have undergone EMT, show a gain of the CSC phenotype [152-155].

Recently, Kurrey et al. have reported a detailed study of genome-wide identification of SNAI1 and SNAI2 targets that resolves the specific mechanism underlying enrichment of stem-like cells post radiation treatment or chemotherapy through EMT [156]. This study identifies a modulation by SNAI1 and SNAI2 toward repressing a newly acquired subset of gene targets under conditions of stress that results in inactivation of p53-mediated apoptosis. This tripartite functioning in which EMT mediates the escape mechanism to newer and less adverse niches,complemented with resistance to apoptosis and acquisition of 'stemness', ensures cell survival under conditions of stress and/or ensures tumor generation that correlates with disease progression. This suggests that such de novo CSC generation arises from a directed dedifferentiation of tumor cells that culminates in selective accumulation of quiescent or resistant cells under conditions of stress. EMT confers the ability to detach from the primary bulk by losing cell adhesive properties and acquire invasive features to cancer cells. Furthermore, cancer cell populations, experimentally induced into EMT, exhibit an increased resistance to chemotherapy and acquisition of SCs properties [157].

\section{Tumor dormancy and CSC quiescence}

Many CSCs stay in G0 and are not susceptible to cell cycle-specific chemotherapeutic agents [158]. Consequently, this sub-population could survive to such treatments and later it is able to regenerate the tumor [159]. However, as described above, the immunity and resistance that occur in CSCs are mainly due to genetic and epigenetic changes, that accumulate mutations and lead to the loss of apoptosis control. These changes include over expression of DNA repair protein MGMT and genes that reduce apoptosis process leading to invasion and metastasis in more advanced stages, including FLIP, Bcl-2, Bcl-XL, HER2/neu and numerous IAP family members. Altered Bcl-2 expression can drastically change drug sensitivity and is associated with resistance to multiple drugs in human cancers such as EOC [160]. Overexpression of proto-oncogene HER2, which encodes a trans-membrane phosphoglycoprotein receptor tyrosine kinase (p185HER2), constitutes an important step in progression, poor prognosis, and clinical outcome of ovarian carcinoma. This event can lead to malignant transformation and plays a crucial role in the tumorigenesis of ovarian cancer. Tumors with high HER2 expression show less sensitivity to anticancer drugs [161-163]. The cell could also maintain its drug insensitivity using epigenetic changes [164]. Thus, CSCs have characteristics that make them responsible for development of chemoresistance in both refractory and recurrent EOC. Hypoxia is another critical factor for cancer malignancy and maintenance of SC characteristics [165-168]. The hypoxia response system acts pleiotropically to upregulate glucose transporters, mainly GLUT1, and multiple enzymes of the glycolytic pathway $[169,170]$. Glycolytic metabolism is associated with activated oncogenes and mutant tumor suppressors.

Multiple ovarian cancer cell lines have been studied in a recent analysis, and in taxane and platinum resistant cell lines; in this study the ALDH1A1 expression and activity were found to be significantly higher. Among patients, $72.9 \%$ of ovarian cancers had ALDH1A1 expression and the percent of ALDH1A1-positive cells correlated negatively with PFS [112].

\section{Therapeutic approaches of ovarian CSCs}

Targeting CSCs might be a strategy to improve outcome of cancer patients but the complexities that lie within this approach will provide many challenges in clinical applications. Combined treatments that target CSCs will be a new direction in the future. Some of these hurdles include overcoming the immune heterogeneity in CSC population as well as the problem of epitopes shared with normal SCs and the necessity to identify additional CSCs antigens. Nevertheless, drug treatment for CSCs may increase the risk of toxicity since CSCs share common features with normal SCs. The current therapeutic strategies in ovarian CSCs are discussed below.

\section{Target therapy: cell surface markers}

Antibody therapies against tumor cell surface antigens have improved clinical prognosis through inhibition of specific signaling pathways, enhancing activation of direct immune effectors. In some cases, antibodies are conjugated with a bioactive drug that enables selective targeting 
of chemotherapeutic agents. In other cases, they block a signaling pathway in which the marker may be involved.

A monoclonal murine anti-human CD133 antibody conjugated to monomethyl-auristatin F (MMAF), a potential cytotoxic drug, has been shown to inhibit growth in hepatocellular and gastric cancer cells in vitro by inducing apoptosis [171].

Several antibodies against CD44v6 isoform have been developed and phase I clinical trials for patients suffering from head and neck squamous cell carcinoma began with high hopes [20,172]. CD44 is a surface adhesion molecule that binds to hyaluronic acid, which is related with tumor progression and metastasis. Hyaluronic acid bioconjugates with paclitaxel are being studied to enhance selective entry of cytotoxic drugs into human EOC cells expressing CD44 and for its use in intraperitoneal treatment of ovarian carcinoma [173].

SWA11, an antibody against CD24,reduced tumor size in xenograft mice transplanted by lung cancer cells A549 and pancreatic cancer cells BxPC3 [174].

In 2009, Su and his colleagues successfully applied short hairpin RNA (shRNA) to reduce CD24 expression. The knockdown of CD24 decreased cell viability by in vitro activation of apoptosis in ovarian cell line SKOV3, also suppressing tumor growth in nude mice bearing ovarian cancer in vivo [175]. Therefore, CD24 inhibition may be considered as an effective approach for cancer therapy.

Imatinib, a potent CD117 (c-KIT) specific inhibitor, has been used in clinical trials for the treatment of many types of cancer, including persistent epithelial ovarian cancer [176].

c-KIT is a receptor tyrosine kinase involved in cell signal transduction. It has been also suggested that CD117 in ovarian carcinoma was associated with poor response to chemotherapy. Therefore, c-KIT could be a perfecttherapeutic target of a tyrosine kinase inhibitor as imatinib. Furthermore, Patel and his colleagues demonstrated that imatinib mesylate is involved in complex cellular processes, including metabolic pathways, cell cycle, cell proliferation, apoptosis, and signal transduction through mass spectrometry-based proteomics method in human ovarian cancer cell line A2780 [177].

EpCAM positive cells also have tumor-initiating potential, making it a potential target for cancer therapy. Catumaxomab, a monoclonal antibody against EpCAM is a trifunctional antibody, which can bind three different cell types, including tumor cells, $\mathrm{T}$ cells, and accessory cells (dendritic cell,macrophages, and natural killer cells) [178].

It is now used in phase III clinical trials in patients with malignant ascites [179].

The investigation of its efficacy and safety was also explored in phase II clinical trials evaluating advanced ovarian cancer patients who had experienced complete chemotherapy. Based on both preclinical and clinical outcomes,
EpCAM may be served as a possible therapeutic target against epithelial ovarian cancer.

ALDH proteins are a superfamily containing 19 enzymes that protect cells from carcinogenic aldehydes [180]. Recently, clinical trials have been initiated using disulfiram (an ALDH inhibitor). The combination of disulfiram with gemcitabine had a synergistic effect on cytotoxicity in glioblastoma multiforme cells [181].

Targets such as CD133 and CD44 could differentiate CSCs from normal cells enabling specific action but indirect strategies,such as interfering with the establishment of an appropriate niche through anti-angiogenic or anti-stromal therapy, could be more effective.

\section{Target therapy: differentiation of CSCs}

One way to treat cancer without removing CSCs is the induction of the differentiation and the loss of their selfrenewal property. Drugs such as retinoic acid or drugs that aim to generate epigenetic changes in the tumor can stimulate CSCs differentiation. In any case, differentiation strategies might impact on proliferation rate, tumoral composition, self-renewal property, and phenotype transdifferentiation.

Retinoic acid and its analogs are the only differentiating agents used because they are modulators of differentiation and proliferation of epithelial cells. Their combined use with chemotherapy has proven to be a good method for treatment of acute promyelocytic leukemia [182,183]. The all-transretinoic acid (ATRA) can inhibit the proliferation and induce the differentiation via inhibition of $\mathrm{Wnt} / \beta$-catenin pathway in head and neck squamous carcinoma CSC [184].

Recently, Whitworth and his colleagues effectively reduced the growth of ovarian CSC with carboplatin combined with three novel retinoid compounds [185]. In addition, specific unsaturated fatty acids (palmitoleic, oleic, and linoleic acids) can trigger adipocyte-like differentiation in many types of cancer cells, including ovarian cancer cell line SKOV3 [186].

In 2012, Yin and his colleagues observed that TWIST1 (a basic helix-loop-helix transcription factor) played a key role in triggering differentiation of EOC [187].

Jain et al. recently reported that p53 (capable for regulating molecular networks) can activate two miRNAs (miR-34a and miR-145). These miRNAs were then shown to prompt differentiation of human embryonic stem cells [188]. Indeed, emerging evidence indicated that miRNAs were involved in self-renewal and differentiation of normal and cancer stem cells. It was suggested that such miRNAs should be a new therapeutic target for cancer treatment [189]. However, more detailed regulation of differentiation remains to be determined. 


\section{Nanoparticles}

Therapeutic nanoparticles (TNPS) consist of a therapeutic element, such as small-molecule drugs, proteins, or peptides, combined with a drug-delivery molecule, such as a polymers or lipids [190]. Given the high rate of recurrent ovarian cancers with chemotherapeutic resistance, the potential for a more efficient and direct delivery system provided by TNP's size and versatility, makes them a potentially proficient treatment system. Five features are defined as being distinguishing for TNPs, and three of them are particularly relevant in treatment of recurrent ovarian cancer. First, their ability to carry a high drug payload without affecting the carrier molecules or ability of the nanoparticle to maneuver itself within tumor tissue, gives them an advantage over antibody conjugated to a targeting ligand. Second, the drugdelivery molecule can be customized to influence the speed of drug release of each specific drug it carries. Finally, TNPs utilize the enhanced permeability and retention (EPR) effect provided by immature, leaky tumor vasculature to localize tumor tissue. TNPs may be endocytosed by target cells, thereby bypassing mechanisms of resistance such as cell-surface protein pumps. The joint effort of the EPR effect and endocytosis method of targeting tumor cells provides a possible twofold benefit in cancer treatment. This approach minimizes side effects of widespread drug delivery and contributes to overcome resistance mechanisms, such as cell-surface protein pumps. In addition to anti-cancer drug delivery, controlled and targeted release through the EPR effect,combined with surface modifications, allow a direct interface with specific CSCs by utilizing particular surface markers, receptors, epitopes, or any other unique features of the CSCs, absent in healthy tissues and normal stem cells. The current TNPs used for ovarian cancer treatment are liposomal doxorubicin, xyotax (or CT-2103), and IT-101. This group of TNPs can be further separated into two groups based on the type of carrier molecule utilized. Liposomal doxorubicin differs from the other two using pegylated liposome molecule as its carrier molecule combined with doxorubicin. The second group consists of Xyotax and IT-101 that utilize polymeric carriers. Xyotax is a combination of poly-L-glutamic acid (PGA) and paclitaxel. IT-101 consists of a cyclodextrin containing polymer combined with camptothecin. One of the advantages that polymer-based TNPs have over lipid-based TNPs is that polymerbased TNPs are able to generate a more controlled drug delivery. The use of TNPs for each of these drugs allows lower drug clearance and a longer half-life [191]. In an in vivo orthotopic mouse model of ovarian cancer, ALDH1A1 silencing using nanoliposomal siRNA sensitized both taxane- and platinum-resistant cell lines to chemotherapy, significantly reducing tumor growth in mice,compared to chemotherapy alone. These data demonstrate that the ALDH1A1 subpopulation is associated with chemoresistance and outcome in ovarian cancer patients, and targeting ALDH1A1 sensitizes resistant cells to chemotherapy. ALDH1A1-positive cells have enhanced, but not absolutely, tumorigenicity, but do have differentiation capacity lacking in ALDH1A1-negative cells [112].

Niches of CSCs: Niches are microenvironments where CSCs reside, containing cell-cell, cell-extracellular matrix, and soluble factors that support the growth, progression, and metastasis of CSCs [192]. Bone-marrow-derived mesenchymal SCs (MSCs) are known to form fibroblast and myofibroblast populations in the tumor-associated stroma. Recently, evidence has been demonstrated that MSC and derived cell types could secrete prostaglandin E2 and release various cytokines, which are vital for the formation and progression of a tumor [193]. Furthermore, MSC affected metastatic ability and chemoresistance in two ovarian cancer cell lines: OVCAR3 and SKOV3 [194].

Katz et al. reported that tumorigenic ability of ovarian tumor cells was dependent on niches derived from human embryonic stem cells [195]. The hypoxic niches were beneficial for acquirement of stem-like properties of ovarian cancer cells [196]. These findings highlight the vital role of CSCs niches, which represent a promising therapeutic target for eradicating CSCs in the future. Indeed, disrupting components in the niches may yield better outcomes without noncytotoxic effect, when compared with that of removing the CSCs [197].

\section{MicroRNAs (miRNAs)}

MiRNAs are a group of small noncoding RNAs with 20-28 nucleotides in length. They could regulate gene expression at post-transcriptional level. Thus, miRNAs are involved in diverse biological processes, such as development and tumorigenesis [198].

The expression profile of miRNAs was different between normal SCs and CSCs [199,200].

MiR-214 was highly expressed in ovarian CSCs and endowed the property of self-renewal and chemoresistance in ovarian CSCs via repressing p53- Nanog pathway [201].

MiR-199a significantly rescued the sensitivity of ovarian CSCs to some chemotherapeutic agents, including cisplatin, paclitaxel, and Adriamycin. Moreover, miR-199a prevented tumorigenesis in xenograft model via downregulating expression of CSCs marker CD44. In addition, the expression of miR-200a could reduce migrating ability of CD133+ ovarian CSCs. This was because miR-200a inhibited E-cadherin and ZEB2, two genes critical for migration process. However, some miRNAs own oncogenic property, such as miR-125, miR-9, miR-30, miR-21 and miR-215 [202,203]. 


\section{Discussion}

Ovarian CSCs are likely to be heterogeneous as well as the EOC itself. Because of its semi-solid character in dissemination and growth, advanced EOC with its hundreds of peritoneal tumor nodules and plaques, appears to be an excellent in vivo model for studying cancer stem cell hypothesis. Until now, no universal single marker has been found to faithfully isolate ovarian CSCs. We can say that, even in multi-passaged cancer cell lines, hierarchic government of growth and differentiation is conserved and that the key CSC population may be composed of small overlapping cell fractions defined by various arbitrary markers.

The high rates and patterns of therapeutic failure seen in patients with EOC are consistent with a steady accumulation of platinum-resistant CSCs. We can say that targeting pathways, involved in this process, could significantly increase tumor sensitivity to platinum therapy, leading to novel treatment strategies upon diagnosis of EOC and recurrence [204-208].

An ideal agent should be able to selectively target CSCs over normal SCs. Without this selectivity, the effectiveness of treatment might be limited by systemic toxicity. It is also likely that treatment of patients with CSC-targeted therapies will require new clinical end points for monitoring therapeutic efficacy. These therapies in fact target only a small fraction of cells within the tumor, not the bulk of tumor. In addition, responses may require a much longer time so that they are typically visible. Rational approaches might also include the use of cytotoxic chemotherapies to target proliferating bulk of tumor in addition to CSC-directed therapy. An important end point would be to control the disease status by checking the size of the CSC population in response to treatment. In this area one strategy could be monitoring the burden of CSCs in circulation.

Microarray and proteomic profiling of CSCs will likely lead to identification of new markers, as well as potential therapeutic targets. CSC markers may have prognostic value by allowing assessment of the size of the CSC population within any selective tumor. Animal transgenic and xenografts model systems described above need to be implemented in order to examine the hallmark characteristics of ovarian CSC and shared by all stem cells, as potential for self-renewal, lineage differentiation and homeostatic control.

The outlook for patients with ovarian cancer may be markedly improved by identifying disease-specific CSCs which are relevant to the development of each subtype of cancer. The involvement of CSCs in chemoresistance and recurrence opens a new avenue to develop new CSCspecific drug-delivery conjugates in the form of aptamers, differentiating agents, miRNA mimics or targeting peptides/ nucleotides. In addition, the application of personalized medicine in the form of a genomic signature (DNA or RNA), even though not yet standardized and integrated into the health system for clinical consideration, may facilitate individual-specific drug and dose selection resulting in better ovarian cancer diagnosis and prognosis.

The rapid increase in our understanding of molecular processes that regulate cancer signatures has raised an equally strong desire to eradicate EOC before the resistance, or relapse that continue to worsen survival data of this disease. Multiple ovarian histophenotypes and the possible sites of disease origin, together with the potential for differential hierarchal contributions of multiple CSCs populations, represent significant challenges for the identification, functional characterization and therapeutic targeting of ovarian CSC.

\section{Competing interests}

The authors declare that they have no competing interests.

\section{Authors' contributions}

FT and AP were the main authors of the manuscript; LR and MS collected and studied the bibliography; PV participated in the sequence alignment and drafted the manuscript; GL corrected the language form; ST drafted the article and revised it critically for important intellectual content. All authors read and approved the final manuscript.

\section{Author details}

'Department of Gynaecology and Obstetrics, University of Rome "Sapienza", Rome, Italy. 'Department of Medico-Surgical Sciences and Biotechnologies, University of Rome "Sapienza", Latina, Italy. ${ }^{3}$ Department of Medical Oncology, National Cancer Institute of Rome, Rome, Italy.

Received: 26 June 2013 Accepted: 29 July 2013

Published: 1 August 2013

\section{References}

1. Murdoch WJ, McDonnel AC: Roles of the ovarian surface epithelium in ovulation and carcinogenesis. Reproduction 2002, 123(6):743-750.

2. Godwin AK, Testa JR, Hamilton TC: The biology of ovarian cancer development. Cancer 1993, 71(2 Suppl):530-536.

3. Ness RB, Cottreau C: Possible role of ovarian epithelial inflammation in ovarian cancer. J Natl Cancer Inst 1999, 91(17):1459-1467.

4. Siegel R, Ward E, Brawley O, Jemal A: Cancer statistics, 2011. CA Cancer J Clin 2011, 61:212-236.

5. Jemal A, Siegel R, Ward E, Hao Y, Xu J, Thun MJ: Cancer statistics, 2009. CA Cancer J Clin 2009, 59:225-249.

6. Boring CC, Squires TS, Tong T: Cancer statistics, 1993. CA Cancer J Clin 1993, 43:7-26.

7. Kusumbe AP, Bapat SA: Ovarian stem cell biology and the emergence of ovarian cancer stem cells. In Cancer Stem Cells. Edited by Bapat S, Hoboken NJ. Hoboken: John Wiley \& Sons Inc; 2008:95-110.

8. Bast RC Jr, Hennessy B, Mills GB: The biology of ovarian cancer: new opportunities for translation. Nature Reviews. Cancer 2009, 9:415-428.

9. Wikborn C, Pettersson F, Silfversward C, Moberg PJ: Symptoms and diagnostic difficulties in ovarian epithelial cancer. Int $J$ Gynaecol Obstet 1993, 42:261-264.

10. Ghasemi R, Grassadonia A, Tinari N, Piccolo E, Natoli C, Tomao F, lacobelli S: Tumor-derived microvesicles: the metastasomes. Medical Hypotheses. Med Hypotheses 2013, 80(1):75-82.

11. Fleming GF, Ronnet BM, Seidman J: Epithelial ovarian cancer. In Principles and Practice of Gynecologic Oncology. 5th edition. Edited by Barakat RR, Markman M, Randal ME. Philadelphia: Lippincot Williams \& Wilkins; 2009:763-836.

12. Kurman RJ, Shih le M: The origin and pathogenesis of epithelial ovarian cancer: a proposed unifying theory. Am J Surg Pathol 2010, 34:433-443. 
13. Kauffman RP, Griffin SJ, Lund JD, Tullar PE: Recommendations for cervical cancer screening: do they render the annual pelvic examination obsolete? Med Princ Pract. in press.

14. Banerjee S, Kaye SB: New strategies in the treatment of ovarian cancer -current clinical perspectives and future potential. Clin Cancer Res. in press.

15. Hennessy BT, Coleman RL, Markman M: Ovarian cancer. Lancet 2009, 374:1371-82.

16. Ozols RF: Update on the management of ovarian cancer. Cancer J 2002, 8(Suppl 3):22-30.

17. Dalerba P, Cho RW, Clarke MF: Cancer stem cells: models and concepts. Annu Rev Med 2007, 58:267-284.

18. Jordan CT, Guzman ML, Noble M: Cancer stem cells. N Engl J Med 2006, 355:1253-1261.

19. Reya T, Morrison SJ, Clarke MF, Weissman IL: Stem cells, cancer, and cancer stem cells. Nature 2001, 414:105-111.

20. Alvero AB, Chen R, Fu HH, Montagna M, Schwartz PE, Rutherford T, Silasi DA, Steffensen KD, Waldstrom M, Visintin I, Mor G: Molecular phenotyping of human ovarian cancer stem cells unravel the mechanisms for repair and chemo-resistance. Cell Cycle 2009, 8(Suppl. 1):158-166.

21. Mor G, Yin G, Chefetz I, Yang Y, Alvero A: Ovarian cancer stem cells and inflammation. Cancer Biol Ther 2011, 11:708-713.

22. Bapat SA, Mali AM, Koppikar CB, Kurrey NK: Stem and progenitor-like cells contribute to the aggressive behavior of human epithelial ovarian cancer. Cancer Res 2005, 65:3025-3029.

23. Lim D, Oliva E: Precursors and pathogenesis of ovarian carcinoma. Pathology 2013, 45(3):229-42.

24. Auersperg N: The origin of ovarian carcinomas: a unifying hypothesis. Int J Gynecol Pathol 2011, 30(1):12-21.

25. Tinelli A, Vergara D, Martignago R, Leo G, Pisanò M, Malvasi A: An outlook on ovarian cancer and borderline ovarian tumors: focus on genomic and proteomic findings. Curr Genomics 2009, 10(4):240-9.

26. Farley J, Ozbun LL, Birrer MJ: Genomic analysis of epithelial ovarian cancer. Cell Res 2008, 18(5):538-48.

27. Heinzelmann-Schwarz VA, Gardiner-Garden M, Henshall SM, Scurry JP, Scolyer RA, Smith AN, Bali A, Vanden Bergh P, Baron-Hay S, Scott C, Fink D, Hacker NF, Sutherland RL, O'Brien PM: A distinct molecular profile associated with mucinous epithelial ovarian cancer. Br J Cancer 2006, 94(6):904-13.

28. Kurrey NK, Amit K, Bapat SA: Snail and slug are major determinants of ovarian cancer invasiveness at the transcription level. Gynecol Oncol 2005, 97:155-165.

29. Zhang S, Balch C, Chan MW, Lai HC, Matei D, Schilder JM, Yan PS, Huang TH, Nephew KP: Identification and characterization of ovarian cancer-initiating cells from primary human tumors. Cancer Res 2008, 68:4311-4320.

30. Deng S, Yang X, Lassus H, Liang S, Kaur S, Ye Q, Li C, Wang LP, Roby KF, Orsulic S, Connolly DC, Zhang Y, Montone K, Bützow R, Coukos G, Zhang L: Distinct expression levels and patterns of stem cell marker, aldehyde dehydrogenase isoform1 (ALDH1), in human epithelial cancers. PLOS ONE 2010, 5:e10277.

31. Silva IA, Bai S, McLean K, Yang K, Griffith K, Thomas D, Ginestier C, Johnston C, Kueck A, Reynolds RK, Wicha MS, Buckanovich RJ: Aldehyde dehydrogenase and CD133 define angiogenic ovarian cancer stem cells that portend poor patient survival. Cancer Res 2011, 71:3991-4001.

32. Dyall S, Gayther SA, Dafou D: Cancer stem cells and epithelial ovarian cancer Oncology: Journal of; 2010:105269.

33. Bast RC Jr, Mills GB: Personalizing therapy for ovarian cancer: BRCAness and beyond. J Clin Oncol 2010, 28(22):3545-3548.

34. Pardal R, Clarke MF, Morrison SJ: Applying the principles of stem-cell biology to cancer. Nat Rev Cancer 2003, 3:895-902.

35. Clarke MF, Dick JE, Dirks PB, Eaves CJ, Jamieson CH, Jones DL, Visvader J, Weissman IL, Wahl GM: Cancer stem cells-perspectives on current status and future directions: AACR Workshop on cancer stem cells. Cancer Res 2006, 66:9339-9344.

36. Kurman RJ, Visvanathan K, Roden R, Wu TC, Shih IM: Early detection and treatment of ovarian cancer: shifting from early stage to minimal volume of disease based on a new model of carcinogenesis. Am J Obstet Gynecol 2008, 198:351-356.

37. Pisano C, Bruni GS, Facchini G, Marchetti C, Pignata S: Treatment of recurrent epithelial ovarian cancer. Ther Clin Risk Manag 2009, 5:421-426.

38. Pujade-Lauraine E, Wagner U, Aavall-Lundqvist E, Gebski V, Heywood M, Vasey PA, Volgger B, Vergote I, Pignata S, Ferrero A, Sehouli J, Lortholary A,
Kristensen G, Jackisch C, Joly F, Brown C, Le Fur N, du Bois A: Pegylated liposomal Doxorubicin and Carboplatin compared with Paclitaxel and Carboplatin for patients with platinum-sensitive ovarian cancer in late relapse. J Clin Oncol 2010, 28:3323-3329.

39. Monk BJ, Herzog TJ, Kaye SB, Krasner CN, Vermorken JB, Muggia FM, Pujade-Lauraine E, Park YC, Parekh TV, Poveda AM: Trabectedin plus pegylated liposomal Doxorubicin in recurrent ovarian cancer. $J$ Clin Oncol 2010, 28:3107-3114

40. Benedetti-Panici P, Perniola G, Marchetti C, Pernice M, Donfrancesco C, Di Donato V, Tomao F, Palaia I, Graziano M, Basile S, Bellati F: Intraperitoneal chemotherapy by ultrasound-guided direct puncture in recurrent ovarian cancer: feasibility, compliance, and complications. Int J Gynecol Cancer 2012, 22(6):1069-74.

41. Tomao F, Panici PB, Frati L, Tomao S: Emerging role of pemetrexed in ovarian cancer. Expert Rev Anticancer Ther 2009, 9(12):1727-35.

42. Bellati F, Napoletano C, Gasparri ML, Ruscito I, Marchetti C, Pignata S, Tomao F, Benedetti Panici P, Nuti M: Current knowledge and open issues regarding bevacizumab in gynecological neoplasms. Crit Rev Oncol Hematol 2012 83(1):35-46.

43. Tomao F, Benedetti Panici P, Tomao S: Improvement in progression free survival in oceans bevacizumab arm: a critical point of view. J Clin Oncol 2013, 31(1):166-7.

44. Guarneri V, Piacentini F, Barbieri E, Conte PF: Achievements and unmet needs in the management of advanced ovarian cancer. Gynecol Oncol 2010, 117(2):152-158.

45. Itamochi H: Targeted therapies in epithelial ovarian cancer: molecular mechanisms of action. World Journal of Biological Chemistry 2010, 1(7):209-220.

46. Croker AK, Allan AL: Cancer stem cells: implications for the progression and treatment of metastatic disease. J Cell Mol Med 2008, 12(2):374-390.

47. Bao S, Wu Q, McLendon RE, Hao Y, Shi Q, Hjelmeland AB, Dewhirst MW, Bigner DD, Rich JN: Glioma stem cells promote radioresistance by preferential activation of the DNA damage response. Nature 2006 444(7120):756-760.

48. Molofsky AV, Pardal R, Morrison SJ: Diverse mechanisms regulate stem cell self-renewal. Curr Opin Cell Biol 2004, 16:700-707.

49. Liu S, Dontu G, Mantle ID, Patel S, Ahn NS, Jackson KW, Suri P, Wicha MS: Hedgehog signaling and Bmi-1 regulate self-renewal of normal and malignant human mammary stem cells. Cancer Res 2006, 66(12):6063-6071.

50. Korkaya H, Paulson A, Charafe-Jauffret E, Ginestier C, Brown M, Dutcher J, Clouthier SG, Wicha MS: Regulation of mammary stem/progenitor cells by PTEN/Akt/B-catenin signaling. PLoS Biol 2009, 7(6):e1000121.

51. Miki J, Furusato B, Li H, Gu Y, Takahashi H, Egawa S, Sesterhenn IA, McLeod DG, Srivastava S, Rhim JS: Identification of putative stem cell markers, CD133 and CXCR4, in hTERTimmortalized primary nonmalignant and malignant tumorderived human prostate epithelial cell lines and in prostate cancer specimens. Cancer Res 2007, 67(7):3153-3161.

52. Charafe-Jauffret $E$, Ginestier C, lovino F, Wicinski J, Cervera N, Finetti P, Hur MH, Diebel ME, Monville F, Dutcher J, Brown M, Viens P, Xerri L, Bertucci F, Stassi G, Dontu G, Birnbaum D, Wicha MS: Breast cancer cell lines contain functional cancer stem sells with metastatic capacity and a distinct molecular signature. Cancer Res 2009, 69(4):1302-1313.

53. Dontu G, Abdallah WM, Foley JM, Jackson KW, Clarke MF, Kawamura MJ, Wicha MS: In vitro propagation and transcriptional profiling of human mammary stem/progenitor cells. Genes Dev 2003,

17(10):1253-1270.

54. Widschwendter M, Fiegl H, Egle D, Mueller-Holzner E, Spizzo G, Marth C, Weisenberger DJ, Campan M, Young J, Jacobs I, Laird PW: Epigenetic stem cell signature in cancer. Nat Genet 2007, 39(2):157-158.

55. Al-Hajj M, Wicha MS, Benito-Hernandez A, Morrison SJ, Clarke MF: Prospective identification of tumorigenic breast cancer cells. Proc Natl Acad Sci USA 2003, 100:3983-3988.

56. Singh SK, Hawkins C, Clarke ID, Squire JA, Bayani J, Hide T, Henkelman RM, Cusimano MD, Dirks PB: Identification of human brain tumour initiating cells. Nature 2004, 432:396-40.

57. Galli R, Binda E, Orfanelli U, Cipelletti B, Gritti A, De Vitis S, Fiocco R, Foroni C, Dimeco F, Vescovi A: Isolation and characterization of tumorigenic, stem-like neural precursors from human glioblastoma. Cancer Res 2007, 64:7011-7021.

58. O'Brien CA, Pollett A, Gallinger S, Dick JE: A human colon cancer cell capable of initiating tumour growth in immunodeficient mice. Nature 2007, 445:106-110. 
59. Ricci-Vitiani L, Lombardi DG, Pilozzi E, Biffoni M, Todaro M, Peschle C, De Maria R: Identification and expansion of human colon-cancer-initiating cells. Nature 2007, 445:111-115.

60. Prince ME, Sivanandan R, Kaczorowski A, Wolf GT, Kaplan MJ, Dalerba P, Weissman IL, Clarke MF, Ailles LE: Identification of a subpopulation of cells with cancer stem cell properties in head and neck squamous cell carcinoma. Proc Natl Acad Sci USA 2007, 104:973-978.

61. Li C, Heidt DG, Dalerba P, Burant CF, Zhang L, Adsay V, Wicha M, Clarke MF, Simeone DM: Identification of pancreatic cancer stem cells. Cancer Res 2007, 67:1030-1037.

62. Dick JE, Bhatia M, Gan O, Kapp U: Assay of human stem cells by repopulation of NOD/SCID mice. Stem Cells 1997, 15(Suppl. 1):199-207.

63. Quintana E, Shackleton M, Sabel MS, Fullen DR, Johnson TM, Morrison SJ: Efficient tumour formation by single human melanoma cells. Nature 2008, 456(7222):593-598.

64. Bonnet D, Dick JE: Human acute myeloid leukemia is organized as a hierarchy that originates from a primitive hematopoietic cell. Nat Med 1997, 3:730-737

65. Dalerba P, Clarke MF: Cancer stem cells and tumor metastasis: first steps into uncharted territory. Cell Stem Cell 2007, 1:241-242.

66. Dalerba P, Dylla SJ, Park IK, Liu R, Wang X, Cho RW, Hoey T, Gurney A, Huang EH, Simeone DM, Shelton AA, Parmiani G, Castelli C, Clarke MF: Phenotypic characterization of human colorectal cancer stem cells. Proc Natl Acad Sci USA 2007, 104:10158-10163.

67. Hill RP: Identifying cancer stem cells in solid tumors: case not proven. Cancer Res 2006, 66:1891-1895.

68. Hill RP, Perris R: "Destemming" cancer stem cells. J Natl Cancer Inst 2007, 99:1435-1440

69. Vogel G: Stem cells. 'Stemness' genes still elusive. Science 2003, 302:371.

70. Orkin SH, Zon LI: Hematopoiesis: an evolving paradigm for stem cell biology. Cell 2008, 132:631-644.

71. McNiece I: The CD34 + Thy1+ cell population: are they all stem cells? Exp Hematol 2000, 28:1312-1314.

72. Zon LI: Intrinsic and extrinsic control of haematopoietic stem-cell self-renewal. Nature 2008, 453:306-313.

73. Yin AH, Miraglia S, Zanjani ED, Almeida-Porada G, Ogawa M, Leary AG, Olweus J, Kearney J, Buck DW: AC133, a novel marker for human hematopoietic stem and progenitor cells. Blood 1997, 90:5002-5012.

74. Shackleton M, Vaillant F, Simpson KJ, Stingl J, Smyth GK, Asselin-Labat ML, Wu L, Lindeman GJ, Visvader JE: Generation of a functional mammary gland from a single stem cell. Nature 2006, 439:84-88.

75. Spangrude GJ, Brooks DM: Mouse strain variability in the expression of the hematopoietic stem cell antigen Ly-6A/E by bone marrow cells. Blood 1993, 82:3327-3332.

76. Corbeil D, Röper K, Hellwig A, Tavian M, Miraglia S, Watt SM, Simmons PJ, Peault B, Buck DW, Huttner WB: The human AC133 hematopoietic stem cell antigen is also expressed in epithelial cells and targeted to plasma membrane protrusions. J Biol Chem 2000, 275(8):5512-5520.

77. Ferrandina G, Bonanno G, Pierelli L, Perillo A, Procoli A, Mariotti A, Corallo M, Martinelli E, Rutella S, Paglia A, Zannoni G, Mancuso S, Scambia G: Expression of CD133-1 and CD133-2 in ovarian cancer. Int J Gynecol Cancer 2008, 18:506-514.

78. Baba T, Convery PA, Matsumura N, Whitaker RS, Kondoh E, Perry T, Huang Z, Bentley RC, Mori S, Fujii S, Marks JR, Berchuck A, Murphy SK: Epigenetic regulation of CD133 and tumorigenicity of CD133+ ovarian cancer cells. Oncogene 2009, 28(2):209-218.

79. Curley MD, Therrien VA, Cummings CL, Sergent PA, Koulouris CR, Friel AM, Roberts DJ, Seiden MV, Scadden DT, Rueda BR, Foster R: CD133 expression defines a tumor initiating cell population in primary human ovarian cancer. Stem Cells 2009, 27(12):2875-83.

80. Heider KH, Kuthan H, Stehle G, Munzert G: CD44v6: a target for antibody-based cancer therapy. Cancer Immunol Immunother 2004, 53:567-579

81. Chen J, Wang J, Chen D, Yang J, Yang C, Zhang Y, Zhang H, Dou J: Evaluation of characteristics of CD44 + CD117+ ovarian cancer stem cells in three dimensional basement membrane extract scaffold versus two dimensional monocultures. BMC Cell Biol 2013, 14:7.

82. Wei X, Dombkowski D, Meirelles K, Pieretti-Vanmarcke R, Szotek PP, Chang HL, Preffer Fl, Mueller PR, Teixeira J, MacLaughlin DT, Donahoe PK: Mullerian inhibiting substance preferentially inhibits stem/progenitors in human ovarian cancer cell lines compared with chemotherapeutics. Proc Natl Acad Sci USA 2010, 107(44):18874-9.

83. Goodell MA, Brose K, Paradis G, Conner AS, Mulligan RC: Isolation and functional properties of murine hematopoietic stem cells that are replicating in vivo. J Exp Med 1996, 183:1797-1806.

84. Kvinlaug BT, Huntly BJ: Targeting cancer stem cells. Expert Opin Ther Targets 2007, 11:915-927.

85. Chiba T, Kita K, Zheng YW, Yokosuka O, Saisho H, Iwama A, Nakauchi H, Taniguchi H: Side population purified from hepatocellular carcinoma cells harbors cancer stem cell-like properties. Hepatology 2006, 44:240-251.

86. Seigel GM, Campbell LM, Narayan M, Gonzalez-Fernandez F: Cancer stem cell characteristics in retinoblastoma. Mol Vis 2005, 11:729-737.

87. Haraguchi N, Utsunomiya T, Inoue H, Tanaka F, Mimori K, Barnard GF, Mori M: Characterization of a side population of cancer cells from human gastrointestinal system. Stem Cells 2006, 24:506-513.

88. Hirschmann-Jax C, Foster AE, Wulf GG, Nuchtern JG, Jax TW, Gobel U, Goodell MA, Brenner MK: A distinct "side population" of cells with high drug efflux capacity in human tumor cells. Proc Natl Acad Sci 2004, 101:14228-14233.

89. Kondo T, Setoguchi T, Taga T: Persistence of a small subpopulation of cancer stem-like cells in the C6 glioma cell line. Proc Natl Acad Sci 2004, 101:781-786.

90. Wulf GG, Wang RY, Kuehnle I, Weidner D, Marini F, Brenner MK, Andreeff M, Goodell MA: A leukemic stem cell with intrinsic drug efflux capacity in acute myeloid leukemia. Blood 2001, 98:1166-1173.

91. Szotek PP, Pieretti-Vanmarcke R, Masiakos PT, Dinulescu DM, Connolly D, Foster R, Dombkowski D, Preffer F, MacLaughlin DT, Donahoe PK: Ovarian cancer side population defines cells with stem cell-like characteristics and Mullerian Inhibiting Substance responsiveness. Proc Natl Acad Sci USA 2006, 103:11154-11159.

92. Moserle L, Indraccolo S, Ghisi M, Frasson C, Fortunato E, Canevari S, Miotti S, Tosello V, Zamarchi R, Corradin A, Minuzzo S, Rossi E, Basso G, Amadori A: The side population of ovarian cancer cells is a primary target of IFN-alpha antitumor effects. Cancer Res 2008, 68:5658-5668.

93. Kristiansen $G$, Sammar M, Altevogt P: Tumour biological aspects of CD24, a mucin-like adhesion molecule. J Mol Histol 2004, 35(3):255-262.

94. Gao MQ, Choi YP, Kang S, Youn JH, Cho NH: CD24+ cells from hierarchically organized ovarian cancer are enriched in cancer stem cells. Oncogene 2010, 29(18):2672-2680.

95. Miettinen M, Lasota J: KIT (CD117): a review on expression in normal and neoplastic tissues, and mutations and their clinicopathologic correlation. Applied Immunohistochemistry and Molecular Morphology 2005, 13(3):205-220.

96. Luo L, Zeng J, Liang B, Zhao Z, Sun L, Cao D, Yang J, Shen K: Ovarian cancer cells with the CD117 phenotype are highly tumorigenic and are related to chemotherapy outcome. Exp Mol Pathol 2011, 91:596-602.

97. Raspollini MR, Amunni G, Villanucci A, Baroni G, Taddei A, Taddei GL: c-KIT expression and correlation with chemotherapy resistance in ovarian carcinoma: an immunocytochemical study. Ann Oncol 2004, 15(4):594-597. 2004.

98. Chau WK, Ip CK, Mak AS, Lai HC, Wong AS: c-Kit mediates chemoresistance and tumor-initiating capacity of ovarian cancer cells through activation of Wnt/beta-catenin-ATP-binding cassette G2 signaling. Oncogene. in press.

99. Imrich S, Hachmeister M, Gires O: EpCAM and its potential role in tumor-initiating cells. Cell Adh Migr 2012, 6:30-38.

100. Pauli C, Münz M, Kieu C, Mack B, Breinl P, Wollenberg B, Lang S, Zeidler R, Gires O: Tumor-specific glycosylation of the carcinoma-associated epithelial cell adhesion molecule EpCAM in head and neck carcinomas. Cancer Lett 2003, 193(1):25-32.

101. Gosens MJEM, Van Kempen LCL, Van De Velde CHJ, Van Krieken JHJM, Nagtegaal ID: Loss of membranous Ep-CAM in budding colorectal carcinoma cells. Mod Pathol 2007, 20(2):221-232.

102. Baeuerle PA, Gires O: EpCAM (CD326) finding its role in cancer. Br J Cancer 2007, 96(3):417-423.

103. Thiery JP, Acloque H, Huang RYJ, Nieto MA: Epithelial-mesenchymal transitions in development and disease. Cell 2009, 139(5):871-890.

104. Moreb JS: Aldehyde dehydrogenase as a marker for stem cells. Curr Stem Cell Res Ther 2008, 3:237-246.

105. Glinsky GV, Olga Berezovska O, Glinskii AB: Microarray analysis identifies a death from cancer signature predicting therapy failure in patients with multiple types of cancer. J Clin Invest 2005, 115:1503-1521. 
106. Shi J, Zhou Z, Di W, Li N: Correlation of CD44v6 expression with ovarian cancer progression and recurrence. BMC Cancer 2013, 13:182.

107. Rosanò L, Cianfrocca R, Spinella F, Di Castro V, Nicotra MR, Lucidi A, Ferrandina G, Natali PG, Bagnato A: Acquisition of chemoresistance and EMT phenotype is linked with activation of the endothelin A receptor pathway in ovarian carcinoma cells. Clin Cancer Res 2011, 17(8):2350-60.

108. Tilly JL, Rueda BR: Minireview: stem cell contribution to ovarian development, function, and disease. Endocrinology 2008, 149:4307-4311.

109. Kobel M, Kalloger SE, Boyd N, McKinney S, Mehl E, Palmer C, Leung S, Bowen NJ, lonescu DN, Rajput A, Prentice LM, Miller D, Santos J, Swenerton $K$, Gilks CB, Huntsman D: Ovarian carcinoma subtypes are different diseases: implications for biomarker studies. PLoS Med 2008, 5(12):e232.

110. Lawrenson K, Gayther SA: Ovarian cancer: a clinical challenge that needs some basic answers. PLoS Med 2009, 6:e25.

111. Tothill IE: Biosensors for cancer markers diagnosis. Semin Cell Dev Biol 2009, 20:55-62.

112. Landen CN Jr, Goodman B, Katre AA, Steg AD, Nick AM, Stone RL, Miller LD, Mejia PV, Jennings NB, Gershenson DM, Bast RC Jr, Coleman RL, Lopez-Berestein G, Sood AK: Targeting aldehyde dehydrogenase cancer stem cells in ovarian cancer. Mol Cancer Ther 2010, 9(12):3186-3199.

113. Wani AA, Sharma N, Shouche YS, Bapat SA: Nuclear-mitochondrial genomic profiling reveals a pattern of evolution in epithelial ovarian tumor stem cells. Oncogene 2006, 25:6336-6344.

114. Frosina G: DNA repair in normal and cancer stem cells, with special reference to the central nervous system. Curr Med Chem 2009, $16: 854-866$.

115. Lee AS, Kahatapitiya P, Kramer B, Joya JE, Hook J, Liu R, Schevzov G, Alexander IE, McCowage G, Montarras D, Gunning PW, Hardeman EC: Methylguanine DNA methyltransferase-mediated drug resistance-based selective enrichment and engraftment of transplanted stem cells in skeletal muscle. Stem Cells 2009, 27:1098-1108.

116. Clarke-Pearson DL: Clinical practice-screening for ovarian cancer. N Engl J Med 2009, 361:170-177.

117. Schwartz PE: Neoadjuvant chemotherapy for the management of ovarian cancer. Best Practice \& Research. Clin Obstet Gynaecol 2002, 16:585-596.

118. Phillips TM, McBride WH, Pajonk F: The response of CD24(-/low)/CD44+ breast cancer-initiating cells to radiation. J Natl Cancer Inst 2006, 98:1777-1785.

119. Blagosklonny MV: Cancer stem cell and cancer stemloids: from biology to therapy. Cancer Biol Ther 2007, 6:1684-1690.

120. Ishii H, Iwatsuki M, leta K, Ohta D, Haraguchi N, Mimori K, Mori M: Cancer stem cells and chemoradiation resistance. Cancer Sci 2008, 99:1871-1877.

121. Hanahan D, Weinberg RA: Hallmarks of cancer: the next generation. Cell 2011, 144:646-674

122. Gimenez-Bonafe P, Tortosa A, Perez-Tomas R: Overcoming drug resistance by enhancing apoptosis of tumor cells. Curr Cancer Drug Targets 2009, 9:320-340.

123. Dean $M: A B C$ transporters, drug resistance, and cancer stem cells. J Mammary Gland Biol Neoplasia 2009, 14:3-9.

124. Szaka'cs G, Paterson JK, Ludwig JA, Booth-Genthe C, Gottesman MM: Targeting multidrug resistance in cancer. Nat Rev Drug Discov 2006, 5:219-234.

125. Donnenberg VS, Meyer EM, Donnenberg AD: Measurement of multiple drug resistance transporter activity in putative cancer stem/progenitor cells. Methods Mol Biol 2009, 568:261-279.

126. Guo Y, Kock K, Ritter CA, Chen ZS, Grube M, Jedlitschky G, Illmer T, Ayres M, Beck JF, Siegmund W, Ehninger G, Gandhi V, Kroemer HK, Kruh GD, Schaich $\mathrm{M}$ : Expression of ABCC-type nucleotide exporters in blasts of adult acute myeloid leukemia: relation to long-term survival. Clin Cancer Res 2009, 15:1762-1769.

127. Martin V, Xu J, Pabbisetty SK, Alonso MM, Liu D, Lee OH, Gumin J, Bhat KP, Colman H, Lang FF, Fueyo J, Gomez-Manzano C: Tie2-mediated multidrug resistance in malignant gliomas is associated with upregulation of $A B C$ transporters. Oncogene 2009, 28:2358-2363.

128. van Herwaarden AE, Wagenaar E, Karnekamp B, Merino G, Jonker JW Schinkel AH: Breast cancer resistance protein (Bcrp1/Abcg2) reduces systemic exposure of the dietary carcinogens aflatoxin B1, IQ and Trp-P-1 but also mediates their secretion into breast milk. Carcinogenesis 2006, 27:123-130.

129. Zhou S, Schuetz JD, Bunting KD, Colapietro AM, Sampath J, Morris JJ, Lagutina I, Grosveld GC, Osawa M, Nakauchi H, Sorrentino BP: The ABC transporter Bcrp1/ABCG2 is expressed in a wide variety of stem cells and is a molecular determinant of the side-population phenotype. Nat Med 2001, 7:1028-1034

130. Alvi AJ, Clayton H, Joshi C, Enver T, Ashworth A, Vivanco M, Dale TC, Smalley MJ: Functional and molecular characterisation of mammary side population cells. Breast Cancer Res 2003, 5:R1-R8.

131. Cervello I, Gil-Sanchis C, Mas A, Delgado-Rosas F, Martínez-Conejero JA, Galán A, Martínez-Romero A, Martínez S, Navarro I, Ferro J, Horcajadas JA, Esteban FJ, O'Connor JE, Pellicer A, Simón C: Human endometrial side population cells exhibit genotypic, phenotypic and functional features of somatic stem cells. PLoS One 2010, 5:e10964.

132. Hosonuma S, Kobayashi Y, Kojo S, Wada H, Seino K, Kiguchi K, Ishizuka B: Clinical significance of side population in ovarian cancer cells. Hum Cell 2011, 24:9-12.

133. Hu L, McArthur C, Jaffe RB: Ovarian cancer stemlike side-population cells are tumourigenic and chemoresistant. Br J Cancer 2010, 102:1276-1283.

134. Grivennikov SI, Greten FR, Karin M: Immunity, inflammation, and cancer. Cell 2010, 140:883-899.

135. Kamazawa S, Kigawa J, Kanamori Y, Itamochi H, Sato S, Iba T, Terakawa N: Multidrug resistance gene-1 is a useful predictor of Paclitaxel-based chemotherapy for patients with ovarian cancer. Gynecol Oncol 2002, 86:171-176.

136. Rodriguez-Antona C: Pharmacogenomics of paclitaxel. Pharmacogenomics 2010, 11:621-623.

137. Anderson ME: Glutathione: an overview of biosynthesis and modulation. Chem Biol Interact 1998, 111-112:1-14.

138. Backos DS, Franklin CC, Reigan P: The role of glutathione in brain tumor drug resistance. Biochem Pharmacol 2012, 83(8):1005-1012.

139. Jedlitschky G, Leier I, Buchholz U, Center M, Keppler D: ATP-dependent transport of glutathione $\mathrm{S}$-conjugates by the multidrug resistance-associated protein. Cancer Res 1994, 54(18):4833-4836.

140. Wu WJ, Zhang Y, Zeng ZL, Li XB, Hu KS, Luo HY, Yang J, Huang P, Xu RH: $\beta$-phenylethyl isothiocyanate reverses platinum resistance by a GSH-dependent mechanism in cancer cells with epithelial-mesenchymal transition phenotype. Biochem Pharmacol 2013, 85(4):486-96.

141. Lessard J, Sauvageau G: Bmi-1 determines the proliferative capacity of normal and leukaemic stem cells. Nature 2003, 423(6937):255-260.

142. Liu J, Cao L, Chen J, Song S, Lee IH, Quijano C, Liu H, Keyvanfar K, Chen H, Cao LY, Ahn BH, Kumar NG, Rovira II, Xu XL, van Lohuizen M, Motoyama N, Deng CX, Finkel T: Bmi1 regulatesmitochondrial function and the DNA damage response pathway. Nature 2009, 459(7245):387-392.

143. Li J, Gong LY, Song LB, Jiang LL, Liu LP, Wu J, Yuan J, Cai JC, He M, Wang L, Zeng M, Cheng SY, Li M: Oncoprotein Bmi-1 renders apoptotic resistance to glioma cells through activation of the IKK-nuclear factor-kappaB-pathway. Am J Pathol 2010, 176(2):699-709.

144. Guo BH, Feng Y, Zhang R, Xu LH, Li MZ, Kung HF, Song LB, Zeng MS: Bmi-1 promotes invasion and metastasis, and its elevated expression is correlated with an advanced stage of breast cancer. Mol Cancer 2011, 10:10.

145. Wang E, Bhattacharyya S, Szabolcs A, Rodriguez-Aguayo C, Jennings NB, Lopez-Berestein G, Mukherjee P, Sood AK, Bhattacharya R: Enhancing chemotherapy response with Bmi-1 silencing in ovarian cancer. PLOS ONE 2011, 6(3):e17918.

146. Fraser M, Bai T, Tsang BK: Akt promotes cisplatin resistance in human ovarian cancer cells through inhibition of $\mathrm{p} 53$ phosphorylation and nuclear function. Int I Cancer 2008, 122(3):534-546.

147. Nikolaev AY, Li M, Puskas N, Qin J, Gu W: Parc: a cytoplasmic anchor for p53. Cell 2003, 112(1):29-40.

148. Woo MG, Xue K, Liu J, McBride H, Tsang BK: Calpain-mediated processing of p53-associated parkin-like cytoplasmic protein (PARC) affects chemosensitivity of human ovarian cancer cells by promoting p 53 subcellular trafficking. J Biol Chem 2012, 287(6):3963-3975.

149. Wallace-Brodeur RR, Lowe SW: Clinical implications of p53 mutations. Cell Mol Life Sci 1999, 55:64-75.

150. Kusumbe AP, Bapat SA: Cancer stem cells and aneuploid populations within developing tumors are the major determinants of tumor dormancy. Cancer Res 2009, 69:9245-9253.

151. Peinado H, Portillo F, Cano A: Transcriptional regulation of cadherins during development and carcinogenesis. Int J Dev Biol 2004, 48:365-375.

152. Mani SA, Guo W, Liao MJ, Eaton EN, Ayyanan A, Zhou AY, Brooks M, Reinhard F, Zhang CC, Shipitsin M, Campbell LL, Polyak K, Brisken C, Yang J, Weinberg RA: The epithelialmesenchymal transition generates cells with properties of stem cells. Cell 2008, 133(4):704-715. 
153. Peinado H, Olmeda D, Cano A: Snail, Zeb and bHLH factors in tumour progression: an alliance against the epithelial phenotype? Nat Rev Cancer 2007, 7:415-428.

154. Zavadil J, Bitzer M, Liang D, Yang YC, Massimi A, Kneitz S, Piek E, Bottinger EP: Genetic programs of epithelial cell plasticity directed by transforming growth factor-beta. PNAS 2001, 98:6686-6691

155. Polyak K, Weinberg RA: Transitions between epithelial and mesenchymal states: acquisition of malignant and stem cell traits. Nat Rev Cancer 2009, 9:265-273.

156. Kurrey NK, Jalgaonkar SP, Joglekar AV, Ghanate AD, Chaskar PD, Doiphode RY, Bapat SA: Snail and Slug mediate radio- and chemo-resistance by antagonizing p53-mediated apoptosis and acquiring a stem-like phenotype in ovarian cancer cells. Stem Cells 2009, 27:2059-2068.

157. Gupta PB, Onder TT, Jiang G, Tao K, Kuperwasser C, Weinberg RA, Lander ES: Identification of selective inhibitors of cancer stem cells by highthroughput screening. Cell 2009, 138:645-659.

158. Wicha MS, Liu S, Dontu G: Cancer stem cells: an old idea-a paradigm shift. Cancer Res 2006, 66:1883-1890.

159. Sell S, Pierce GB: Maturation arrest of stem cell differentiation is a common pathway for the cellular origin of teratocarcinomas and epithelial cancers. Lab Invest 1994, 70:6-22.

160. Reed EC: Cisplatin. Cancer Chemother Biol Response Modif 1999, 18:144-151.

161. Rolitsky CD, Theil KS, McGaughy VR, Copeland LJ, Niemann TH: HER-2/neu amplification and overexpression in endometrial carcinoma. Int J Gynecol Pathol 1999, 18:138-143.

162. Slamon DJ, Godolphin W, Jones LA, Holt JA, Wong SG, Keith DE, Levin WJ, Stuart SG, Udove J, Ullrich A: Studies of the HER-2/neu proto-oncogene in human breast and ovarian cancer. Science 1989, 244:707-712.

163. Kim JW, Lee CG, Lyu MS, Kim HK, Rha JG, Kim DH, Kim SJ, Namkoong SE: A new cell line from human undifferentiated carcinoma of the ovary: establishment and characterization. J Cancer Res Clin Oncol 1997, 123:82-90

164. Perez-Caro M, Cobaleda C, Gonzalez-Herrero I, Vicente-Dueñas C, Bermejo-Rodríguez C, Sánchez-Beato M, Orfao A, Pintado B, Flores T, Sánchez-Martín M, Jiménez R, Piris MA, Sánchez-García I: Cancer induction by restriction of oncogene expression to the stem cell compartment. EMBO J 2009, 28:8-20.

165. Lara PC, Lloret M, Clavo B, Apolinario RM, Henríquez-Hernández LA, Bordón E, Fontes F, Rey A: Severe hypoxia induces chemo-resistance in clinical cervical tumors through MVP over-expression. Radiat Oncol 2009, 4:29.

166. Elloul S, Vaksman O, Stavnes HT, Trope CG, Davidson B, Reich R: Mesenchymal-to-epithelial transition determinants as characteristics of ovarian carcinoma effusions. Clin Exp Metastasis 2010, 27:161-172.

167. Pistollato F, Abbadi S, Rampazzo E, Persano L, Della Puppa A, Frasson C, Sarto E, Scienza R, D'avella D, Basso G: Intratumoral hypoxic gradient drives stem cells distribution and MGMT expression in glioblastoma. Stem Cells 2010, 28:851-862.

168. Greijer AE, van der Groep P, Kemming D, Shvarts A, Semenza GL, Meijer GA, van de Wiel MA, Belien JA, van Diest PJ, van der Wall E: Upregulation of gene expression by hypoxia is mediated predominantly by hypoxia-inducible factor 1 (HIF-1). J Pathol 2005, 206(3):291-304.

169. Levine AJ, Puzio-Kuter AM: The control of themetabolic switch in cancers by oncogenes and tumor suppressor genes. Science 2010, 3(330(6009)):1340-4.

170. DeBerardinis RJ: Is cancer a disease of abnormal cellular metabolism? New angles on an old idea. Genet Med 2008, 10:767-777.

171. Smith LM, Nesterova A, Ryan MC, Duniho S, Jonas M, Anderson M, Zabinski RF, Sutherland MK, Gerber HP, Van Orden KL, Moore PA, Ruben SM, Carter PJ: CD133/prominin-1 is a potential therapeutic target for antibody-drug conjugates in hepatocellular and gastric cancers. Br J Cancer 2008, 99:100-109.

172. Orian-Rousseau V: CD44, a therapeutic target for metastasizing tumours. Eur J Cancer 2010, 46:1271-7.

173. De Stefano I, Battaglia A, Zannoni GF, Prisco MG, Fattorossi A, Travaglia D, Baroni S, Renier D, Scambia G, Ferlini C, Gallo D: Hyaluronic acid-paclitaxel: effects of intraperitoneal administration against CD44(+) human ovarian cancer xenografts. Cancer Chemother Pharmacol 2011, 68(1):107-16.

174. Bretz NP, Salnikov AV, Perne C, Keller S, Wang X, Mierke CT, Fogel M, Erbe-Hofmann N, Schlange T, Moldenhauer G, Altevogt P: CD24 controls Src/ STAT3 activity in human tumors. Cell Mol Life Sci 2012, 69(22):3863-3879.

175. Su D, Deng H, Zhao X, Zhang X, Chen L, Chen X, Li Z, Bai Y, Wang Y, Zhong Q, Yi T, Qian Z, Wei Y: Targeting CD24 for treatment of ovarian cancer by short hairpin RNA. Cytotherapy 2009, 11(5):642-652.
176. Schilder RJ, Sill MW, Lee RB, Shaw TJ, Senterman MK, Klein-Szanto AJ, Miner Z, Vanderhyden BC: Phase II evaluation of imatinib mesylate in the treatment of recurrent or persistent epithelial ovarian or primary peritoneal carcinoma: a gynecologic oncology group study. J Clin Oncol 2008, 26(20):3418-3425.

177. Patel BB, He YA, Li XM, Frolov A, Vanderveer L, Slater C, Schilder RJ, von Mehren M, Godwin AK, Yeung AT: Molecular mechanisms of action of imatinib mesylate in human ovarian cancer: a proteomic analysis. Cancer Genomics Proteomics 2008, 5:137-150.

178. Sebastian M, Kuemmel A, Schmidt M, Schmittel A: Catumaxomab: a bispecific trifunctional antibody. Drugs of Today 2009, 45(8):589-597.

179. Seimetz D, Lindhofer H, Bokemeyer C: Development and approval of the trifunctional antibody catumaxomab (anti- EpCAM $\times$ anti-CD3) as a targeted cancer immunotherapy. Cancer Treat Rev 2010, 36(6):458-467.

180. Marchitti SA, Brocker C, Stagos D, Vasiliou V: Non-P450 aldehyde oxidizing enzymes: the aldehyde dehydrogenase superfamily. Expert Opin Drug Metab Toxicol 2008, 4(6):697-720.

181. Liu P, Brown S, Goktug T, Channathodiyil P, Kannappan V, Hugnot JP, Guichet PO, Bian X, Armesilla AL, Darling JL, Wang W: Cytotoxic effect of disulfiram/copper on human glioblastoma cell lines and ALDH positive cancer-stem-like cells. Br J Cancer 2010, 107(9):1488-1497.

182. Soignet SL, Benedetti F, Fleischauer A, Parker BA, Truglia JA, Ra Crisp M, Warrell RP Jr: Clinical study of 9-cis retinoic acid (LGD1057) in acute promyelocytic leukemia. Leukemia 1998, 12(10):1518-1521.

183. Sell S: Stem cell origin of cancer and differentiation therapy. Crit Rev Oncol Hematol 2004, 51(1):1-28.

184. Lim YC, Kang HJ, Kim YS, Choi EC: All-trans-retinoic acid inhibits growth of head and neck cancer stem cells by suppression ofWnt/beta-catenin pathway. Eur J Cancer 2012, 48(17):3310-3318.

185. Whitworth JM, Londoño-Joshi Al, Sellers JC, Oliver PJ, Muccio DD, Atigadda VR, Straughn JM Jr, Buchsbaum DJ: The impact of novel retinoids in combination with platinum chemotherapy on ovarian cancer stem cells. Gynecol Oncol 2012, 125(1):226-230.

186. Ruiz-Vela A, Aguilar-Gallardo C, Martínez-Arroyo AM, Soriano-Navarro M, Ruiz V, Simón C: Specific unsaturated fatty acids enforce the transdifferentiation of human cancer cells toward adipocyte-like cells. Stem Cell Rev 2011, 7(4):898-909.

187. Yin G, Alvero AB, Craveiro V, Holmberg JC, Fu HH, Montagna MK, Yang Y, Chefetz-Menaker I, Nuti S, Rossi M, Silasi DA, Rutherford T, Mor G: Constitutive proteasomal degradation of TWIST-1 in epithelial-ovarian cancer stem cells impacts differentiation and metastatic potential. Oncogene 2013, 32:39-49.

188. Jain AK, Allton K, lacovino M, Mahen E, Milczarek RJ, Zwaka TP, Kyba M, Barton MC: p53 regulates cell cycle and microRNAs to promote differentiation of human embryonic stem cells. PLoS Biol 2012, 10(2):1001268.

189. Yu Z, Li Y, Fan H, Liu Z, Pestell RG: miRNAs regulate stem cell self-renewal and differentiation. Frontiers in Genetics 2012, 3:191-195.

190. Davis ME, Chen ZG, Shin DM: Nanoparticle therapeutics: an emerging treatment modality for cancer. Nat Rev Drug Discov 2008, 7(9):771-782.

191. Chen ZG: Small-molecule delivery by nanoparticles for anticancer therapy. Trends Mol Med 2010, 16(12):594-602

192. Ruiz-Vela A, Aguilar-Gallardo C, Simón C: Building a framework for embryonic microenvironments and cancer stem cells. Stem Cell Reviews and Reports 2010, 5(4):319-327.

193. Li HJ, Reinhardt F, Herschman HR, Weinberg RA: Cancer stimulated mesenchymal stemcells create a carcinoma stem cell niche via prostaglandin E2 signaling. Cancer Discovery 2012, 2:840-855.

194. Lis R, Touboul C, Raynaud CM, Malek JA, Suhre K, Mirshahi M, Rafii A: Mesenchymal cell interaction with ovarian cancer cells triggers pro-metastatic properties. PLoS One 2012, 7(5):38340.

195. Katz E, Skorecki K, Tzukerman M: Niche-dependent tumorigenic capacity of malignant ovarian ascites-derived cancer ceil subpopulations. Clin Cancer Res 2009, 15(1):70-80.

196. Liang D, Ma Y, Liu J, Trope CG, Holm R, Nesland JM, Suo Z: The hypoxic microenvironment upgrades stem-like properties of ovarian cancer cells. BMC Cancer 2012, 12:201-211.

197. La Barge MA: The difficulty of targeting cancer stem cell niches. Clin Cancer Res 2010, 16(12):3121-3129.

198. Bartel DP: MicroRNAs: target recognition and regulatory functions. Cell 2009, 136(2):215-233. 
199. Lavon I, Zrihan D, Granit A, Einstein O, Fainstein N, Cohen MA, Cohen MA, Zelikovitch B, Shoshan Y, Spektor S, Reubinoff BE, Felig Y, Gerlitz O, Ben-Hur T, Smith Y, Siegal T: Gliomas display a microRNA expression profile reminiscent of neural precursor cells. Neuro Oncol 2010, 12(5):422-433.

200. van Jaarsveld MTM, Helleman J, Berns EMJJ, Wiemer EAC: MicroRNAs in ovarian cancer biology and therapy resistance. Int J Biochem Cell Biol 2010, 42(8):1282-1290.

201. Xu CX, Xu M, Tan L, Yang H, Permuth-Wey J, Kruk PA, Wenham RM, Nicosia SV, Lancaster JM, Sellers TA, Cheng JQ: MicroRNA MiR-214 regulates ovarian cancer cell stemness by targeting p53/Nanog. J Biol Chem 2012, 287(42):34970-34978.

202. Cheng W, Liu T, Wan X, Gao Y, Wang H: MicroRNA-199a targets CD44 to suppress the tumorigenicity and multidrug resistance of ovarian cancer-initiating cells. FEBS J 2012, 279(11):2047-2059.

203. Wu Q, Guo R, Lin M, Zhou B, Wang Y: MicroRNA- 200a inhibits CD133/1+ ovarian cancer stem cells migration and invasion by targeting E-cadherin repressor ZEB2. Gynecol Oncol 2011, 122(1):149-154.

204. Sarkar FH, Li Y, Wang Z, Kong D, Ali S: Implication of microRNAs in drug resistance for designing novel cancer therapy. Drug Resist Updat 2010, 13(3):57-66

205. Zhong X, Li N, Liang S, Huang Q, Coukos G, Zhang L: Identification of microRNAs regulating reprogramming factor LIN28 in embryonic stem cells and cancer cells.J Biol Chem 2010, 285(53):41961-41971.

206. Djordjevic B, Stojanovic S, Conic I, Jankovic-Velickovic L, Vukomanovic P, Zivadinovic R, Vukadinovic M: Current approach to epithelial ovarian cancer based on the concept of cancer stem cells. J BUON 2012, 17(4):627-36.

207. Chefetz I, Alvero AB, Holmberg JC, Lebowitz N, Craveiro V, Yang-Hartwich Y, Yin G, Squillace L, Gurrea Soteras M, Aldo P, Mor G: TLR2 enhances ovarian cancer stem cell self-renewal and promotes tumor repair and recurrence. Cell Cycle 2013, 12(3):511-21.

208. Kang KS, Choi YP, Gao MQ, Kang S, Kim BG, Lee JH, Kwon MJ, Shin YK, Cho NH: CD24(+) ovary cancer cells exhibit an invasive mesenchymal phenotype. Biochem Biophys Res Commun 2013, 432(2):333-8.

doi:10.1186/1756-9966-32-48

Cite this article as: Tomao et al:: Emerging role of cancer stem cells in the biology and treatment of ovarian cancer: basic knowledge and therapeutic possibilities for an innovative approach. Journal of

Experimental \& Clinical Cancer Research 2013 32:48.

\section{Submit your next manuscript to BioMed Central and take full advantage of:}

- Convenient online submission

- Thorough peer review

- No space constraints or color figure charges

- Immediate publication on acceptance

- Inclusion in PubMed, CAS, Scopus and Google Scholar

- Research which is freely available for redistribution 